\title{
RICE LODGING RESISTANCE
}

\author{
E.R. Avakyan, R.R. Dzhamirze \\ Russian Rice Research Institute \\ Krasnodar, 350921, Russian Federation \\ dzhamirze01022010@yandex.ru
}

\begin{abstract}
The main direction of breeding grain crops is to increase yield and improve grain quality. For maximum crop yield, it is necessary to develop cultivars with high productivity and quality potential, resistant to biotic and abiotic environmental factors. One of the main characteristics is lodging. Resistance to lodging is determined by well-defined morphological traits: plant height, diameter of the lower internode, panicle length, angle of leaf plate, etc. Short plants are more resistant to lodging than tall ones. Short straw trait can be used when evaluating cultivars for lodging resistance. The ratio of plant height to the diameter of the lower internode is an objectively reliable indicator of rice lodging resistance. The value of this ratio in non-lodging cultivars is less in comparison with lodging ones. The article presents the results of studying morphological traits of different rice cultivars, determining resistance of rice plant to lodging. In the experiment, cultivars differing in height was grouped into three groups (I - tall; II — medium and III — short). Short stem forms were established to be more resistant to lodging. Accents in breeding high-yielding rice cultivars with the lowest risk of yield loss resulting from lodging were identified. The correlation analysis revealed a positive relationship $(\mathrm{r}=0.877 ; 0.945$ and 0.500 , respectively, in groups) between grain mass per plant and diameter of the lower internode. This indicates a close genetic relationship of the traits studied.
\end{abstract}

Key words: lodging, morphological traits, characterizing resistance trait, productivity

\section{INTRODUCTION}

Lodging is a complex process that expresses the response of a plant to the effects of biotic and abiotic environmental factors. It leads to significant, often to irreversible losses and may occur due to reasons of an objective and subjective nature. The latter include cultivation technology violations (even insignificant; unbalanced mineral nutrition (excess nitrogen supply, leading to intensive vegetative growth, tissue softening, stem thinning; poor checks layout, untimely flooding and discharge of irrigation water, high contamination, high plant density, wrong herbicide treatment, etc.). Weather conditions (rain, wind, hail, extreme temperatures) during the growing season can also lead to lodging.

The main of the reasons should be considered a hereditary genetic trait of the cultivar, due to the level of endogenous gibberellins (GA). GAs are specific phytohormones of rice capable of being incorporated into rice metabolism and causing a wide range of responses. In particular, the increased content of GAs in the plant initiates internode lengthening, plant height, thinning of the stem diameter, and susceptibility to diseases and pests, which causes lodging due to pathogens and insects injuries of lower internode [1]. A prerequisite for the successful development of lodging resistant cultivars is knowledge of distinctive traits that characterize non-lodging and lodging cultivars. Lodging resistance of cultivars depends on plant architectonics, in particular, the angle 
of leaf deviation from the stem: the smaller this angle is, the more the cultivar is resistant to lodging [2-4]. Lodging occurs because the plant cannot balance its growth under certain conditions [5]. Lodging should be considered as a plant reaction affecting certain aspects of the metabolism, in particular, substances that make up mechanical tissues of the stem [6]. Structural polysaccharides protect tissue cells and organisms, give them shape and support it. Resistance to lodging is caused by the content and distribution of mineral elements, silica, in particular, and cellulose in various plant organs. Mineral silicon in rice tissues is present mainly in the form of silica gel, filling aperture in cellulose micelle of cell walls, forming a silicon-cuticular double layer. The layers of silica gel are bound to the layers of cellulose in cell walls, mainly in external and mechanical tissues. A close correlation is noted in epidermis, sclerenchyma, vascular bundles, straw internodes and leaf sheaths [7].

As lodging resistance is a complex trait, including the qualitative and quantitative characteristics of plants, morphological characteristics were studied. For this, the plants selected after full ripeness were used to determine plant height, diameter of the lower internode, head length, ratio of head length to diameter of the lower internode, number of filled and non-filled grains, mass of 1000 grains, and yield. Semi-dwarf (medium growth) cultivars have the most favorable combination of these characteristics [8]. The direct dependence of plant height and lodging was revealed. Depending on straw length rice forms are divided into dwarf (up to $50 \mathrm{~cm}$ ), short $(51-80 \mathrm{~cm}$ ), medium $(81-110 \mathrm{~cm})$, tall $(111-140 \mathrm{~cm})$, very tall (more than $140 \mathrm{~cm})$. Floating rice plants can have a straw up to $500 \mathrm{~cm}$ long. Such a difference in straw length leads to a different location in space [9].

The stem of rice straw is formed by sheaths of leaves, reaching different lengths. The straw is divided by stem nodes into internodes with a thickness of $0.4-1.5 \mathrm{~cm}$. A single layer of epidermis is on straw surface. The outer wall of epidermal cells is thickened and enriched with silica. Layer of intercellular parenchyma has ring of sclerenchyma fibers with thickening around the circumference where collateral closed conductive bundles occur. Cavity formed after death of parenchyma cells is in the center of the straw.

Short stem forms are more resistant to lodging than tall stem plants. The trait of a short straw can serve as an indicator (in combination with others) for selection for plant resistance to lodging. The lower internode is shorter in lodging resistant plants than that of the lodging ones [10].

All the above stated made it possible to formulate the purpose of the study to study the morphobiological traits of various rice genotypes that contribute to lodging resistance.

\section{MATERIALS AND METHODS}

Rice cultivars of Russian Rice Research Institute collection were studied. They were previously grouped by plant height:

1) tall $(111-140 \mathrm{~cm})$ - Aromir, Fisht and Nafant;

2) medium $(81-110 \mathrm{~cm})$ - Privolny-4, Kumir and Favorit;

3) short $(51-80 \mathrm{~cm})$ - Ryzhik, Mavr and Sonet. 
The experiment had four replications. Each plot size was $7.2 \mathrm{~m}^{2}(5.19 \times 1.4 \mathrm{~m})$ having eight rows, distance between the rows was $15 \mathrm{~cm}$, distance between the plots was 40 and $50 \mathrm{~cm}$. Mineral fertilizers were applied in soil before sowing $-\mathrm{N}_{120} \mathrm{P}_{60} \mathrm{~K}_{40}$ and in tillering stage $-\mathrm{N}_{100}$. Soybean was a precursor crop. The research work was carried out in accordance with GOST 15.101.80 'The order of research work' and the methods developed in Russian Rice Research Institute [11] and the methodology of experimental work on breeding [12].

The experimental part of the research was carried out in field conditions in rice irrigation system of experimental production department of Russian Rice Research Institute. Sowing dates were end of April to beginning of May. Samples (10 plants from each replecation) were taken during full ripeness to determine morphological characteristics. The main anatomical and morphological, and lodging traits were measured: plant height, diameter of the first internode, grain mass per plant, productive tillering. Ratio of stem height to diameter of the lower internode was calculated, and correlation of the described traits was determined $[12,13]$.

\section{RESULTS AND DISCUSSION}

Phenological observations and biometric analysis showed that the strength of rice straws is limited by plant height, diameter of the lower internode and mass of generative organs (grain formed). The experiment was optimal in combination of these traits in cultivars with different plant height (Table 1).

Table 1

Anatomical, morphological and biometric traits of different rice cultivars

\begin{tabular}{|l|l|c|c|c|c|c|}
\hline Group & Cultivar & $\begin{array}{c}\text { Plant } \\
\text { height, } \\
\text { cm, (h) }\end{array}$ & $\begin{array}{c}\text { Productive } \\
\text { tillering, } \\
\text { stems }\end{array}$ & $\begin{array}{c}\text { Grain } \\
\text { mass per } \\
\text { plant, g }\end{array}$ & $\begin{array}{c}\text { Diameter } \\
\text { of the lower } \\
\text { internode, } \\
\text { cm, (d) }\end{array}$ & $\begin{array}{c}\text { Ratio of the stem } \\
\text { height to the diam- } \\
\text { eter of lower inter- } \\
\text { node, (h/d) }\end{array}$ \\
\hline \multirow{4}{*}{ I } & Aromir & 118 & 1.8 & 4.8 & 0.54 & 218.5 \\
\cline { 2 - 7 } & Fisht & 122 & 1.6 & 5.7 & 0.60 & 203.3 \\
\cline { 2 - 7 } & Nafant & 117 & 1.5 & 5.5 & 0.56 & 209.0 \\
\hline \multirow{4}{*}{ II } & Privolny-4 & 90 & 2.1 & 4.4 & 0.50 & 180.0 \\
\cline { 2 - 7 } & Kumir & 87 & 2.0 & 4.7 & 0.52 & 177.3 \\
\cline { 2 - 7 } & Favorit & 92 & 2.0 & 4.6 & 0.52 & 145.8 \\
\cline { 2 - 7 } & Ryzhik & 70 & 3.1 & 4.5 & 0.48 & 155.3 \\
\cline { 2 - 7 } & Mavr & 73 & 3.3 & 4.1 & 0.47 & 156.9 \\
\hline LSD $_{05}$ & Sonet & 80 & 2.8 & 4.4 & 0.51 & \\
\hline
\end{tabular}

The data presented show that lodging resistance is different for the cultivars studied. Non-lodging cultivars had a smaller value of this indicator in comparison with lodging ones. The cultivars studied are resistant to lodging, however, the results obtained demonstrate their susceptibility to lodging in stressful environmental conditions. So, cultivars of the I-th group (Aromir, Fisht and Nafant) are potentially lodging, since the value of the resistance index exceeds 200. Cultivars of the second group (Privolny-4, Kumir and Favorit) are less susceptible to lodging and cultivars of the third group (Ryzhik, Mavr and Sonet) have the maximum resistance to lodging. 


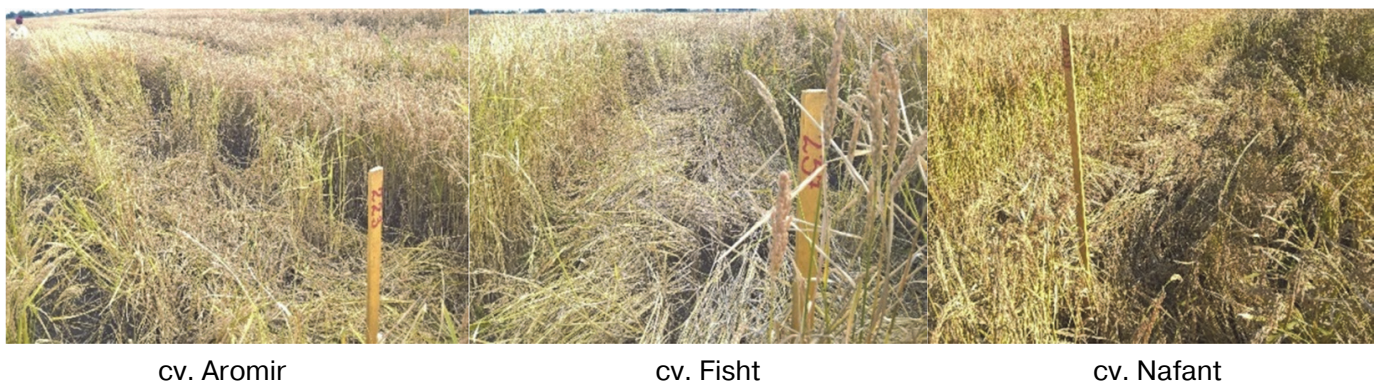

Fig. 1. Lodging of tall rice cultivars, 2018

Table 2

Correlation of traits of rice plants of different varieties

\begin{tabular}{|c|c|c|c|c|c|c|c|}
\hline Group & Trait & $\begin{array}{l}\text { Mean } \\
\text { value }\end{array}$ & $\begin{array}{l}\text { Disper- } \\
\text { sion }\end{array}$ & $\begin{array}{c}\text { Plant } \\
\text { height, } \\
\text { cm (h) }\end{array}$ & $\begin{array}{l}\text { Produc- } \\
\text { tive till- } \\
\text { ering, } \\
\text { stems }\end{array}$ & $\begin{array}{c}\text { Grain } \\
\text { mass } \\
\text { per } \\
\text { plant, g }\end{array}$ & $\begin{array}{c}\text { Diame- } \\
\text { ter of the } \\
\text { lower } \\
\text { inter- } \\
\text { node, } \\
\mathrm{cm},(\mathrm{d})\end{array}$ \\
\hline \multirow[t]{5}{*}{1} & Plant height, cm, (h) & 119.0 & 2.646 & & & & \\
\hline & Productive tillering, stems & 1.6 & 0.153 & 0.000 & & & \\
\hline & Grain mass per plant, $\mathrm{g}$ & 5.33 & 0.473 & 0.520 & -0.854 & & \\
\hline & $\begin{array}{l}\text { Diameter of the lower internode, } \\
\mathrm{cm},(\mathrm{d})\end{array}$ & 0.57 & 0.031 & 0.866 & -0.500 & 0.877 & \\
\hline & $\begin{array}{l}\text { Ratio of stem height to diameter } \\
\text { of lower internode, }(\mathrm{h} / \mathrm{d})\end{array}$ & 210.3 & 7.679 & -0.655 & 0.756 & -0.986 & -0.945 \\
\hline \multirow[t]{5}{*}{ II } & Plant height, $\mathrm{cm},(\mathrm{h})$ & 89.7 & 2.517 & & & & \\
\hline & Productive tillering, stems & 2.0 & 0.058 & 0.115 & & & \\
\hline & Grain mass per plant, $\mathrm{g}$ & 4.57 & 0.153 & -0.434 & -0.945 & & \\
\hline & $\begin{array}{l}\text { Diameter of the lower internode, } \\
\mathrm{cm},(\mathrm{d})\end{array}$ & 0.51 & 0.012 & -0.115 & -0.999 & 0.945 & \\
\hline & $\begin{array}{l}\text { Ratio of stem height to diameter } \\
\text { of lower internode, }(\mathrm{h} / \mathrm{d})\end{array}$ & 174.8 & 6.638 & 0.804 & 0.683 & -0.884 & -0.683 \\
\hline \multirow[t]{5}{*}{ III } & Plant height, $\mathrm{cm},(\mathrm{h})$ & 74.3 & 5.132 & & & & \\
\hline & Productive tillering, stems & 3.1 & 0.252 & -0.761 & & & \\
\hline & Grain mass per plant, $\mathrm{g}$ & 4.33 & 0.208 & -0.016 & -0.636 & & \\
\hline & $\begin{array}{l}\text { Diameter of the lower internode, } \\
\mathrm{cm},(\mathrm{d})\end{array}$ & 0.49 & 0.021 & 0.858 & -0.986 & 0.500 & \\
\hline & $\begin{array}{l}\text { Ratio of stem height to diameter } \\
\text { of lower internode, }(\mathrm{h} / \mathrm{d})\end{array}$ & 152.7 & 6.000 & 0.816 & -0.246 & -0.591 & 0.403 \\
\hline
\end{tabular}

Cultivars with index exceeding 200 are characterized by relatively moderate resistance to lodging, however, they may be susceptible under adverse environmental conditions or non-compliance with agricultural technology (high doses of nitrogen fertilizers, wrong irrigation regime, high plant density, etc.) (Figure 1).

Nature and closeness of correlation of economically valuable traits in the studied rice cultivars indicates specificity of plant metabolism in each group, due to the genotype (Table 2).

The resulted obtained show that diameter of the lower internode positively correlates with height $(r=0.866$ and 0.858$)$ in cultivars of I and III groups, respectively. It indicates an increase in the values of one trait with a similar change of the other one. In plants 
of group II, this correlation is mediated and insignificant $(r=-0.115)$. The negative correlation of straw diameter with productive tillering of the groups presented indicates the biological regularity of assimilates distribution and the growth of vegetative organs, i.e. the diameter of each stem decreases with an increase in the stem number.

It was found that grain mass per plant correlates positively with straw diameter in all groups. Cultivars of I and II group had close correlation of these characteristics ( $r=0.877$ and 0.945 , respectively) that indicates increasing in straw diameter with an increase in productivity at genetic level. And there is an average correlation of these characteristics $(r=0.500)$ in short rice cultivars. This suggests the potential for increasing grain mass per plant with a constant straw diameter or - that these traits are indirectly related.

In conclusion, it should be noted that breeding of new rice cultivars should be aimed not only at increasing yields and technological characteristics of rice grain quality, but also at keeping formed yield when adverse environmental conditions occur (rains, gusty wind, etc.) during harvesting.

\section{CONCLUSIONS}

The quantitative values of the studied traits in cultivars and their role in lodging resistance were presented.

It was established that cultivars of I and II group were in the zone of rice yield loss. In this connection, the breeder in his work should select parental forms not only with high productivity and quality of grain and milled rice, but also with a complex of morphological traits: with thickened internodes, a large number of internodes, high silicon content, etc., which give additional mechanical strength to the stem.

Short stem forms (group III) were more resistant to lodging, which was due to morphological traits and the ability to not only form a high yield, but also to keep it. The results obtained allow breeders to work on increasing yield of short stem cultivars without any lodging risk.

A positive correlation between grain mass per plant and diameter of the lower internode was established; it indicates a close genetic correlation between these traits.

\section{REFERENCES}

1. Avakyan ER, Aleshin NE, Aleshin EP. Mechanism of gibberellin action on rice. Agricultural biology. 1988; 3:9-19. (In Russ).

2. Paleev AM. Biological basis of irrigated agriculture. Moscow: ANUSSR Publishing; 1957. (In Russ).

3. Dzhamirze RR, Avakyan ER. New morphotype of rice plant. Typical features. Enthusiasts of agrarian science. 2007; 8:53-27. (In Russ).

4. Loskutov IG. Oats (Avena L.) Distribution, taxonomy, Evolution and breeding value. SaintPetersburg: SSC RF VIR Publishing; 2007. (In Russ).

5. Petinov NS. The current state of research work on lodging crops and the main promising areas. Minsk; 1965. (In Russ).

6. Leninger A. Bases of biochemistry. Moscow: Mir Publishing; 1985. (In Russ).

7. Avakyan ER. Physiological and biochemical aspects of rice growth and development. Krasnodar: VNIIR Publ.; 2017. (In Russ). 
8. Lyakhovkin AG. Physical and mechanical features of rice vegetative organs in connection with plant lodging. VIR Bulletin. 1971; 18:38 - 43. (In Russ).

9. Aleshin EP, Aleshin NE. Rice. Moscow: Zavodskaya Pravda Publ.; 1993. (In Russ).

10. Strutskovskaya ES. Methods for evaluating wheat raw material for lodging resistance. Breeding and seed production. 1968; 2:28-31. (In Russ).

11. Kovalev VS, Ostapenko NV. Improving the methods and techniques of laying competitive rice varietal testing. In: Abstracts from the conference of young scientists and specialists. Krasnodar; 1987. p.10-12. (In Russ).

12. Smetanin AP, Dzyuba VA, Aprod AI. Methods of experimental work on breeding, seed production and quality control of rice seeds. Krasnodar; 1972. (In Russ).

13. Sheudzhen AK, Bondareva TN. Methods of agrochemical research and statistical evaluation of their results: study guide. 2nd ed. revised and enlarged. Maikop: Polygraph-Yug Publishing; 2015.

\title{
INFORMATION ABOUT AUTHORS
}

Avakyan Elmira Rubenovna - Doctor of Biologycal Sciences, professor, leading researcher of Russian Rice Research Institute.

Dzhamirze Ruslan Ramazanovich - Candidate of Agricultural Sciences, senior researcher of Breeding department, Russian Rice Research Institute. E-mail: dzhamirze01022010@yandex.ru.

ORCID 0000-0003-2862-7254.

SPIN-code: 4475-5890.

\section{For citation:}

Avakyan ER, Dzhamirze RR. Rice lodging resistance. RUDN Journal of Agronomy and Animal Industries, 2018. T. 13. № 4. C. 366-372. doi: 10.22363/2312-797X-2018-13-4-366-372.

\section{УСТОЙЧИВОСТЬ РАСТЕНИЙ РИСА К ПОЛЕГАНИЮ}

\author{
Э.Р. Авакян, Р.P. Джамирзе \\ Всероссийский научно-исследовательский институт риса \\ Краснодар, 350921, Россия \\ dzhamirze01022010@yandex.ru
}

Главным направлением селекции зерновых культур является увеличение урожайности и улучшение качественных показателей зерна. Для формирования растениями максимального урожая необходимо создание сортов с высоким потенциалом продуктивности и качества, устойчивостью к биотическим и абиотическим факторам окружающей среды. Одной из основных характеристик, играющих важную роль, является полегание. Устойчивость к полеганию обусловливается вполне определенными морфологическими признаками: высотой растения, диаметром нижнего междоузлия, длиной метелки, углом расположения листовой пластины к стеблю и т. д. Низкорослые формы более устойчивы к полеганию, нежели высокорослые. Признак короткой соломины может быть использован при оценке сортообразцов на устойчивость к полеганию. Отношение высоты растения к диаметру нижнего междоузлия - объективно надежный показатель устойчивости растения риса к полеганию. Величина этого отношения у неполегающих сортов меньше в сравнении с полегающими. В данной статье представлены результаты изучения морфологических признаков разных сортов риса и степень их взаимосвязи, определяющая в целом устойчивость растения риса к полеганию. Для проведения эксперимента сорта, различающиеся по высоте растения сгруппированы 
в три группы (I - высокорослые; II - среднерослые и III - низкорослые). Установлено, что короткостебельные формы более устойчивы к полеганию и имеют потенциальную возможность сформировать и удержать более увесистую (продуктивную) метелку. Определены акценты в селекции высокоурожайных сортов риса с наименьшим риском потери урожая в результате полегания растений. Методом корреляционного анализа выявлена положительная связь $(r=0,877 ; 0,945$ и 0,500 соответственно по группам) между массой зерна с растения и диаметром нижнего междоузлия. Это свидетельствует о тесной генетической связи изученных признаков.

Ключевые слова: полегание, морфологические признаки, отличительный признак устойчивости, продуктивность

\section{БИБЛИОГРАФИЧЕСКИЙ СПИСОК}

1. Авакян Э.Р., Алёшин Н.Е., Алёшин Е.П. О механизме действия гиббереллина на рис // Сельскохозяйственная биология. 1988. № 3. С. 9-19.

2. Палеев А.М. Полегание злаков и пути борьбы с ним // Биологические основы орошаемого земледелия. М.: АНСССР, 1957. С. 595-610.

3. Джамирзе Р.Р., Авакян Э.Р. Новый морфотип растения риса. Характерные признаки // Энтузиасты аграрной науки. 2007. № 8. С. 53-27.

4. Лоскутов И.Г. Овес (Avena L.). Распространение, систематика, эволюция и селекционная ценность. СПБ.: ГНЦ РФ Вир, 2007. 336 с.

5. Петинов Н.С. Современное состояние научно-исследовательских работ по полеганию зерновых культур и основные перспективные направления // Устойчивость растений против полегания: Тезисы к совещанию, Минск, 1965. Вып. 29. С. 3-13.

6. Ленинджер А. Основы биохимии. Т. 1. М.: Мир, 1985. 367 с.

7. Авакян Э.Р. Физиолого-биохимические аспекты роста и развития риса. Краснодар: ВНИИР, 2017. $168 \mathrm{c}$.

8. Ляховкин А.Г. Физико-механические особенности вегетативных органов риса в связи с полеганием растений // Бюл. ВИР. 1971. Вып. 18. С. $38-43$.

9. Алешин Е.П., Алешин Н.Е. Рис. М.: Заводская правда, 1993. 505 с.

10. Струияковская Е.С. Методы оценки исходного материала пшеницы на устойчивость к полеганию // Селекция и семеноводство. 1968. № 2. С. $28-31$.

11. Ковалёв В.С., Остапенко Н.В. Совершенствование методики и техники закладки конкурсного сортоиспытания риса // Тезисы докладов конференции молодых ученых и специалистов. Краснодар, 1987. С. 10-12.

12. Сметанин А.П., Дзюба В.А., Апрод А.И. Методики опытных работ по селекции, семеноводству, семеноведению и контролю за качеством семян риса. Краснодар: ВНИИ риса, 1972. $156 \mathrm{c}$.

13. Шеуджен А.Х., Бондарева Т. Н. Методика агрохимических исследований и статистическая оценка их результатов: учеб. пособие. 2 изд. перераб. и доп. Майкоп: ОАО Полиграф-ЮГ, $2015.664 \mathrm{c}$.

\section{Для цитирования:}

Авакян Э.Р., Джамирзе Р.Р. Устойчивость растений риса к полеганию // Вестник Российского университета дружбы народов. Серия: Агрономия и животноводство. 2018. Т. 13. № 4. С. 366372. doi: 10.22363/2312-797X-2018-13-4-366-372. 